\title{
ERBB2 NP_004439.2:p.D769H
}

National Cancer Institute

\section{Source}

National Cancer Institute. ERBB2 NP 004439.2:p.D769H. NCI Thesaurus. Code C155302.

A change in the amino acid residue at position 769 in the receptor tyrosine-protein kinase erbB-2 protein where aspartic acid has been replaced by histidine. 